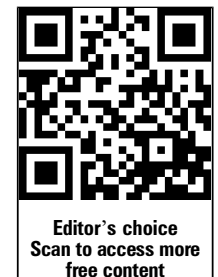

${ }^{1}$ Surgical Sciences, Orthopaedic Surgery, Health Sciences, Dunedin School of Medicine, University of Otago, Dunedin, Otago, New Zealand and the New Zealand Defence Force ${ }^{2}$ Impact and Armour Group, Department of Engineering and Applied Science, Cranfield Defence and Security, Defence Academy of the United Kingdom, Shrivenham, Wiltshire, UK

${ }^{3}$ University of Angers, Angers, France

${ }^{4}$ Sir John Walsh Research Institute, University of Otago, Dunedin, Otago, New Zealand

\section{Correspondence to} Capt Dr D C Kieser,

Surgical Sciences, Orthopaedic Surgery, Health Sciences, Dunedin School of Medicine, University of Otago, PO Box 6458, Dunedin, Otago 9016, New Zealand; kieserdavid@gmail.com

Received 27 March 2013 Accepted 29 April 2013 Published Online First 4 June 2013
To cite: Kieser DC, Carr DJ, Leclair SCJ, et al. J R Army Med Corps 2013;159: 294-299.

\title{
Gunshot induced indirect femoral fracture: mechanism of injury and fracture morphology
}

\author{
David C Kieser, ${ }^{1}$ D J Carr, ${ }_{1}^{2}$ S C J Leclair, ${ }^{3}$ I Horsfall, ${ }^{2}$ J C Theis, ${ }^{1}$ M V Swain, ${ }^{4}$ \\ J A Kieser ${ }^{4}$
}

\section{ABSTRACT}

Introduction Indirect ballistic fractures occur when a projectile passes close to, but not contacting, the bone. The mechanism of how these fractures occur is not yet proven, but recently the acoustic shockwave has been excluded as a cause. The objective of this study is to determine whether the expanding temporary cavity, the collapse of this cavity or its oscillation causes these fractures. In addition, we describe the fracture morphology and biomechanical causes of this injury.

Method 40 fresh deer femora were strain gauged and embedded in ballistic gelatin before being shot with four different projectiles with varying distances off the bone. Pressure recordings, chronographs and radar allowed assessment of local pressures and energy transfer. Highspeed video allowed the temporal relationship between the temporary cavity and fracture formation to be analysed, while sample dissection allowed the fracture morphology to be described.

Results The fractures produced were consistently wedge-shaped and caused by the expansion of the temporary cavity, flexing the bone beyond its yield point, causing tension failure on the cortex opposite the expanding temporary cavity and a compression wedge on the side of the cavity. Local pressure was not predictive of fracture formation but the energy transfer to the gelatin block was predictive.

Conclusions Indirect fractures are caused by the expansion of the temporary cavity and relate to the proximity of this cavity to the bone. Fractures occur from flexion of the bone and classically display wedge-shaped fracture patterns with the apex of the wedge pointing away from the expanding cavity.

\section{INTRODUCTION}

Gunshot injuries represent a common injury in both the military and civilian settings. Internationally, gunshot injuries account for the death of 500000 people annually. ${ }^{1}$ In the USA, there are over 115000 civilian missile-associated injuries per annum, ${ }^{2}$ including 80000 gunshot wounds, $45 \%$ of which involve a fracture. ${ }^{3}$ Since 11 September 2001, over 41000 US soldiers have been reportedly wounded in action in Iraq or Afghanistan. ${ }^{4}$ Improved body protection has reduced the mortality of battlefield casualties, ${ }^{5} 6$ but increased the percentage of injuries involving the limbs to $50 \%-70 \%$. $^{7}$ Consequently, the orthopaedic problems facing survivors and surgeons have increased. ${ }^{8}$

With such high numbers, a complete understanding of the effect of bullet penetration on the skeletal system is required. It is known that upon impact a shockwave is generated that traverses the tissues as a

\section{Key messages}

Indirect fractures occur from the expansion of the temporary cavity.

- Radial displacement of tissues rather than local pressure causes fracture.

- Energy transfer to the tissues and its subsequent temporary cavity are the principal determinant of fracture.

- The closer the bullet passes to bone the more likely indirect fracture is to occur.

- These fractures display a classic wedge-shaped fracture pattern.

hemispherical arc preceding the bullet passage, ${ }^{9}$ but this only lasts for a few microseconds, which is believed to prevent it from causing significant tissue injury. ${ }^{9-12}$ In addition to this shock wave, the bullet crushes and lacerates tissues directly within its path and generates lateral pressures, which force tissues apart. The latter results in an expanding temporary cavity ${ }^{13-15}$ of up to 12.5 times the diameter of the bullet. ${ }^{16}$ The temporary cavity has been said to generate up to 200 atmospheres $(3000 \mathrm{psi}$ ) of pressure,${ }^{17}$ although more recently this has been debated and revised to around two atmospheres ${ }^{18}$ and lasts $5-10 \mathrm{~ms},{ }^{9} 1920$ giving it sufficient time to distort tissues and potentiate more widespread damage.

After full expansion of the temporary cavity, the negative pressure within the cavity aggressively collapses it, drawing tissues back towards their origin and sucking foreign material into the wound. ${ }^{21-25}$ The temporary cavity then reforms and collapses several times, distorting the surrounding tissues repetitively, thereby further damaging them. ${ }^{26}$ Once this oscillation ceases, a permanent cavity remains, representing the crushed, lacerated and expelled tissues. ${ }^{27} 28$

Fractures may result from direct impact of a projectile with a bone or indirectly, where the projectile traverses close to, but not contacting the bone. Indirect fractures were first described by Callender and French in $1935^{29}$ and were first shown on high-speed flash $\mathrm{x}$-ray by $\mathrm{Harvey}^{30}$ with a cat model. Such fractures are not infrequently encountered, although their prevalence is not known. However, our understanding of these fractures is still developing.

While indirect fractures are classically described as simple, ${ }^{31}{ }^{32}$ their exact fracture patterns have not been described. Proposed causative mechanisms 
of these fractures include the sonic shock wave advancing through the soft tissues shattering the bone, expansion or collapse of the temporary cavity displacing the bone, or the oscillation of the cavity fracturing the bone through fatigue. ${ }^{20} 32-34$

Recently, Dougherty et $a l^{32}$ examined bony wounds resulting from 9 and $5.56 \mathrm{~mm}$ bullets fired at fresh frozen cadaveric diaphyseal tibia (2) and femora (26) embedded in ordinance gelatin. High-speed video and temporal strain gauging clearly suggested that a fracture resulted from the temporary cavity rather than the sonic shockwave. However, this study did not determine whether it was the expansion of the temporary cavity, its collapse or oscillation that lay at the cause of bony fracture.

The aim of this current study is to investigate the mechanism of injury by correlating fracture patterns with slow motion videography and biomechanical testing to determine how bone breaks in a gunshot wound, where the bullet misses the bone.

\section{METHOD}

A total of 40 fresh adult female red deer (Cervus elaphus) rear femora attained from a venison processing plant, disarticulated through the hip and stripped of muscle, within $1 \mathrm{~h}$ of slaughter were used. They were immediately refrigerated at $4^{\circ} \mathrm{C}$ and kept moist with saline soaked gauze $(0.9 \% \mathrm{NaCl})$, for a maximum of 4 days, and were debrided of remaining soft tissues, leaving the periosteum intact. A small window of periosteum $(10 \times 20 \mathrm{~mm})$ was excised from the lateral cortex of the mid-diaphysis and two unipolar strain gauges (TML FLA2-23 120 Ohm gauges) applied in a longitudinal and transverse direction following the method described by Roberts ${ }^{35}$ and Biewener. ${ }^{36}$ The gauges were connected to a $40 \mathrm{~cm}$ double lumen conduction wire and insulated with protective electrical lacquer (Ambersil acrylic conformal coating).

The strain-gauged bone was then embedded to a depth of $8 \mathrm{~cm}$ in 18 (depth) $\times 18$ (breadth) $\times 30 \mathrm{~cm}$ (length) rectangular containers of $20 \%$ 250B ballistic gelatin (Weishardt International), made by mixing lukewarm water to $8 \mathrm{~kg}$ of gelatin in a cement mixer. A concentration of $20 \%$ gelatin was used because it is often quoted as the standard NATO concentration and represents the closest density to muscle. ${ }^{34} 37$ The bone's anterior cortex faced the surface of the gel and its long axis parallel to the long axis of the gel. The samples were left to solidify overnight at room temperature $\left(8^{\circ} \mathrm{C}\right)$.

On extraction, the blocks were positioned $10 \mathrm{~m}$ from a number 3 Enfield pressure housing fitted with appropriate barrels, with the anterior cortex facing the barrel. The bullet path was aimed with a barrel-mounted laser to pass with varying distances medial to the medial cortex of the bone. After injury, all samples were dissected to assess fracture patterns and verify the distance from the bone to the permanent cavity.

The strain gauges were connected to a high bandwidth data capture system through a Wheatstone bridge to a transducer amplifier (Flyde FE-H379-TA) and the data captured on an Imatek C3008 data acquisition system, running Impact V.3 software (Imatek). The strain gauges were shunt calibrated in situ. A pressure sensor (Kistler type 7005 sn113590) was inserted into a $1 \mathrm{~cm}^{3}$-excised area of gel on its medial side at the same depth as the bone and height as the bullet trajectory, oriented perpendicular to the bullet path. This was connected to a charge amplifier (Kistler type 5041) in the Imatek C3008 and detected the peak pressure before being dislodged from the gel.

A high-speed video camera (Phantom V12; 40000 frames per second) was positioned on the lateral side of the block and a $45^{\circ}$ mirror positioned above the sample, giving synchronised images in the sagittal and axial planes. The sample was backlit from both directions. Whole bone movement was defined as linear movement of a line intersecting the midpoint of the intercondylar groove and greater trochanter. Flexion was defined as mid-diaphyseal movement away from this line.

The strain gauge and pressure recordings were triggered by two parallel aluminium foils $2 \mathrm{~mm}$ apart, connected to a simple electrical circuit and placed on the entry surface of the gel. As the bullet passed through the foils, the circuit was shorted triggering the time dependent strain and pressure data recordings. This also allowed synchronisation with the video as the bullet passage through the foils is seen on the recorded impacts.

Four different bullets were used: $5.56 \times 45 \mathrm{~mm}$ full metal jacket steel tip (NATO SS109), $9 \times 19 \mathrm{~mm}$ full metal jacket (DM1 1A1B2), 0.44" magnum semijacketed hollow-point (Remington MG43) and a $7.62 \times 39 \mathrm{~mm}$ full metal jacket mild steel core (M43, Russian, Factory 71, 1984). Pre-impact and post-impact bullet velocities were recorded by a Doppler radar and verified by three pairs of sky-screens (MSI, Type 858) either side of the target. These calculations assumed that projectile weight did not vary pre-impact and post-impact.

\section{RESULTS}

A total of 40 samples were shot, but three bullets hit the bone and were excluded, leaving 37 samples for analysis: 15 with $5.56 \times 45 \mathrm{~mm}$ (mass $4.089 \mathrm{~g}$, mean impact velocity $970 \mathrm{~m} / \mathrm{s}$ ), 14 with $0.44^{\prime \prime}(15.505 \mathrm{~g}, 487 \mathrm{~m} / \mathrm{s})$, four with $7.62 \times 39 \mathrm{~mm}$ $(7.952 \mathrm{~g}, 758 \mathrm{~m} / \mathrm{s})$ and four with $9 \times 19 \mathrm{~mm}(7.998 \mathrm{~g}, 408 \mathrm{~m} / \mathrm{s})$ bullets. Fractures were produced by the $5.56 \times 45 \mathrm{~mm}$ up to $1 \mathrm{~cm}$ off the bone (three samples) and the $0.44^{\prime \prime}$ up to $3 \mathrm{~cm}$ off the bone (six samples). The $7.62 \times 39$ and $9 \times 19 \mathrm{~mm}$ both failed to fracture the bone after four shots $1-2 \mathrm{~cm}$ off the bone.

For the $5.56 \times 45 \mathrm{~mm}$, the bullet traversed to a depth of $10 \mathrm{~cm}$ in the gelatin before starting to yaw, with its maximum yaw and hence the expanding cavity's epicentre developing at an average depth of $14 \mathrm{~cm}$ (range 8-17 cm) (Figure 1). This cavity expanded as an elliptical cylinder with its axis parallel to the bullet trajectory and an average diameter of $14 \mathrm{~cm}(11-20 \mathrm{~cm})$.

This expanding cavity impacted the bone, displacing and flexing it in an antero-lateral direction (Figure 2). Flexion greater than $3 \mathrm{~mm}$ fractured the bone with a transverse fracture on the antero-lateral surface and a wedge directed posteromedially towards the temporary cavity's epicentre (Figure 3 ).

The expanding cavity in the case of the $0.44^{\prime \prime}$ bullet (Figure 4) started at the gel surface, due to the bullet deformation, and expanded as a narrow cone encompassing the entire depth of the gel $(20 \mathrm{~cm}$ long), reaching a maximum diameter of $16 \mathrm{~cm}(12-20 \mathrm{~cm})$, at a depth of $15 \mathrm{~cm}(10-20 \mathrm{~cm})$. Note that these values are greater than the preimpact size of the gel, as the block is inflated by the temporary cavity.

Bone movement was seen to change from an antero-lateral direction for bullets passing $1-2 \mathrm{~cm}$ from the bone to a purely lateral direction at $3 \mathrm{~cm}$ and a progressively more postero-lateral direction beyond $4 \mathrm{~cm}$. This was due to two factors: first, the closer bullet tracts flexed the bone in a postero-lateral direction and this artificially forced the condyles to move in a principally anterior direction. Second, the expanding cavity expanded more rapidly at a depth of $10 \mathrm{~cm}$ and this contacted the bone first with closer bullet tracts, but with more distant bullet tracts, the more superficial parts of the temporary cavity had a greater effect on the bone, displacing it in a progressively more posterolateral direction. When bone flexion was significant (Figure 2), a transverse fracture on the postero-lateral surface and a wedge directed antero-medially occurred. More substantial 
Figure 1 Time sequence of $5.56 \times 45 \mathrm{~mm}$ bullet (impact velocity of $970 \mathrm{~m} / \mathrm{s}$ ) shot $1 \mathrm{~cm}$ adjacent to the bone. Note the entry is from the right of each photograph and the exit on the left.
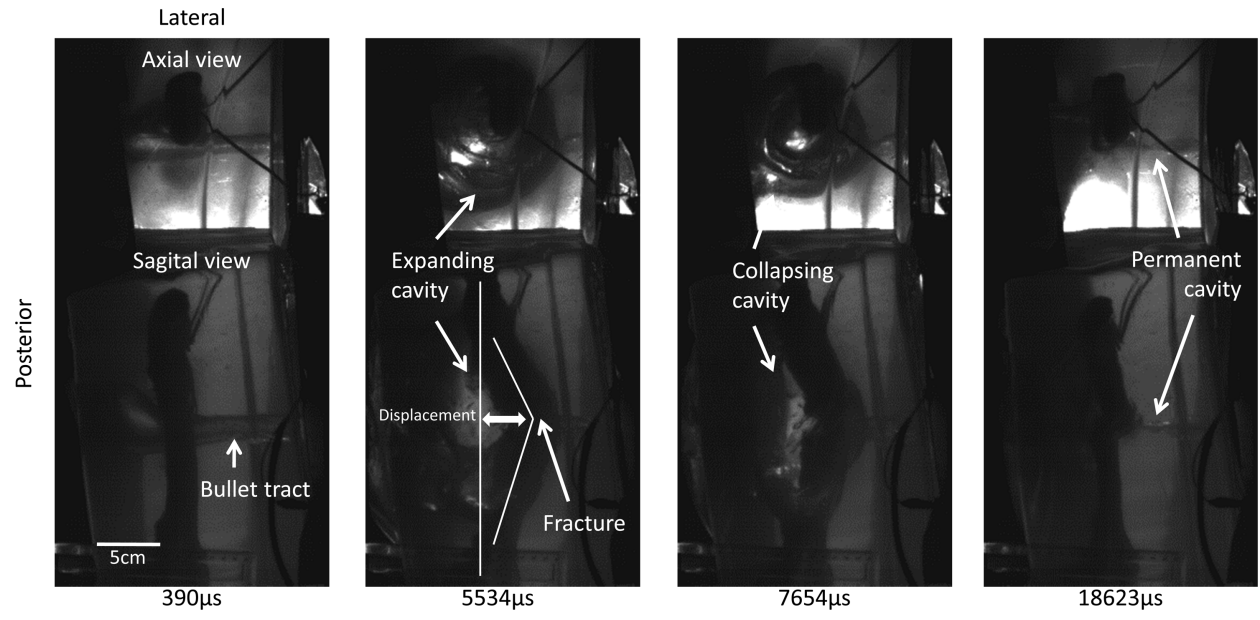

comminution of the fractured bone was seen with closer bullet tracts (Figure 5).

The $7.62 \times 39$ and $9 \times 19 \mathrm{~mm}$ failed to develop significant temporary cavities (maximum diameters of 10 and $5 \mathrm{~cm}$, respectively) and failed to produce bone fracture. However, pressure recordings revealed the highest pressures (Figure 6) and pressure rise rates occurred for tracts closest to the sensor $(1 \mathrm{~cm})$ and reduced the further away the bullet passed, with the highest values seen for the $5.56 \times 45$ and $7.62 \times 39 \mathrm{~mm}$.

Strain gauge results were variable with no clear trend. Prior to commencing this study, the authors expected the bones to flex directly laterally as the bullet passed the medial cortex. This was not the case and therefore the gauges did not account for the direction of flexure, which varied with variable bullet calibres and distances from the bone. This precluded accurate results from this technique even when vector analysis of the lateral force was analysed. However, the synchronisation of the gauges to the video revealed that fracture, corresponding to a high strain peak, occurred on the expansion of the temporary cavity. If no fracture occurred, a sinusoidal pattern of strain was seen.

The energy transfer or loss of energy during transit of the gelatin, as determined by change in kinetic energy of the projectile, showed a clear difference between those bullets that caused fracture (1600-1800 J) and those that did not (400-500 J).

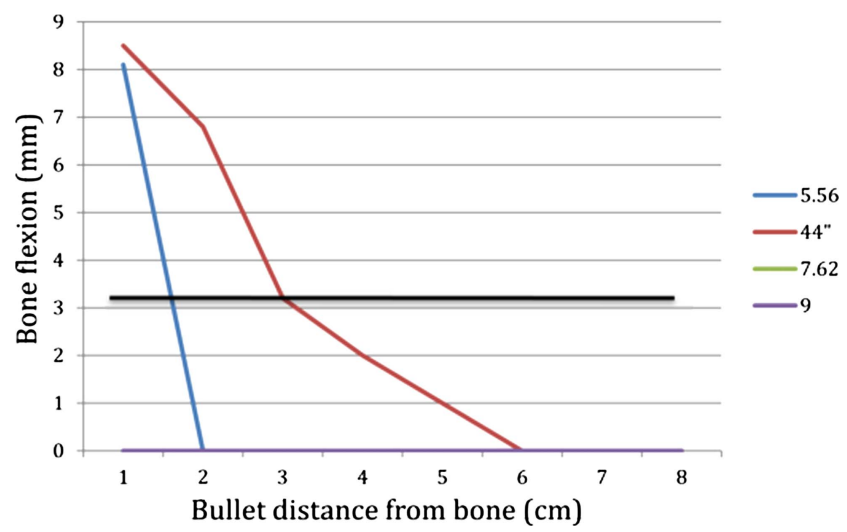

Figure 2 Amount of bone flexion with varying calibres and bullet distances from bone. The black line at $3 \mathrm{~mm}$ represents the minimum flexion required to cause fracture. Note: The $7.62 \times 39$ and $9 \times 19 \mathrm{~mm}$ failed to cause any bone flexion.

\section{DISCUSSION}

Indirect fractures are seen when a bullet traverses close to, but does not contact, the bone. ${ }^{32}$ However, a complete understanding of how this fracture occurs is still developing.

This study convincingly shows, with slow motion video, that it is the expansion of the temporary cavity, rather than the shock wave, the collapsing of the temporary cavity or its oscillation that fractures the bone. It is also confirmed by fracture patterns, being, at least in our experimental setup, consistently wedge-shaped with the apex of the wedge seen at the sight of highest tension on the 'far' cortex and the base closest to the expanding cavity. The position of the 'far' cortex depends on where the maximum temporary cavity expansion occurs within the ballistic gelatin and this is determined by the projectile design. For example, like previous authors, we found that the $0.44^{\prime \prime}$ hollow point bullet mushrooms on impact increasing its diameter 2-3 times, developing its expanding temporary cavity from the gel surface. ${ }^{38}$ We noted that this results in the cavity impacting the bone from an antero-medial direction flexing the bone on its postero-lateral surface, resulting in a transverse fracture of the postero-lateral surface with a wedge-shaped fracture extending onto the antero-medial surface. In contrast, the $5.56 \times 45 \mathrm{~mm}$, which we, like others, noted to enter the gel with little initial deformation, started to yaw around the $10 \mathrm{~cm}$ depth, resulting in an expanding cavity with its epicentre being at a depth of $14 \mathrm{~cm} .{ }^{10}$ We found that this cavity expanded as an enlarging sphere, impacting the bone on its postero-medial surface flexing it in an antero-lateral direction. In this situation, a transverse fracture on the antero-lateral surface and a wedge extending towards the postero-medial surface was seen.

The transverse fracture, which we found at the apex of the wedge, is suggested by other papers to occur when the bone fails in tension, whereas the wedge occurs from compression. ${ }^{39} 40$ This pattern is consistent with the bone fracturing from forced flexion caused by the expansion of the temporary cavity, rather than the shock wave, which would only fracture in one direction, as the pressure wave expands from the impact site, or the collapsing of the temporary cavity, which would have the same fracture pattern, but in the opposite direction. These results concur with the video and strain gauge findings, which show fracture occurring during the expansion of the temporary cavity.

Similar results were found by Dougherty et $a l^{32}$ who, like others, described simple fracture patterns, but did not analyse these in detail, but did analyse the temporal relationship between a $5.56 \times 45 \mathrm{~mm}$ bullet passage and fracture using 
Figure 3 Indirect fracture from a $5.56 \times 45 \mathrm{~mm}$ bullet passing $1 \mathrm{~cm}$ off the medial aspect of the mid-femur, showing tension failure on the antero-lateral cortex and a spat-out compression wedge on the postero-medial cortex.

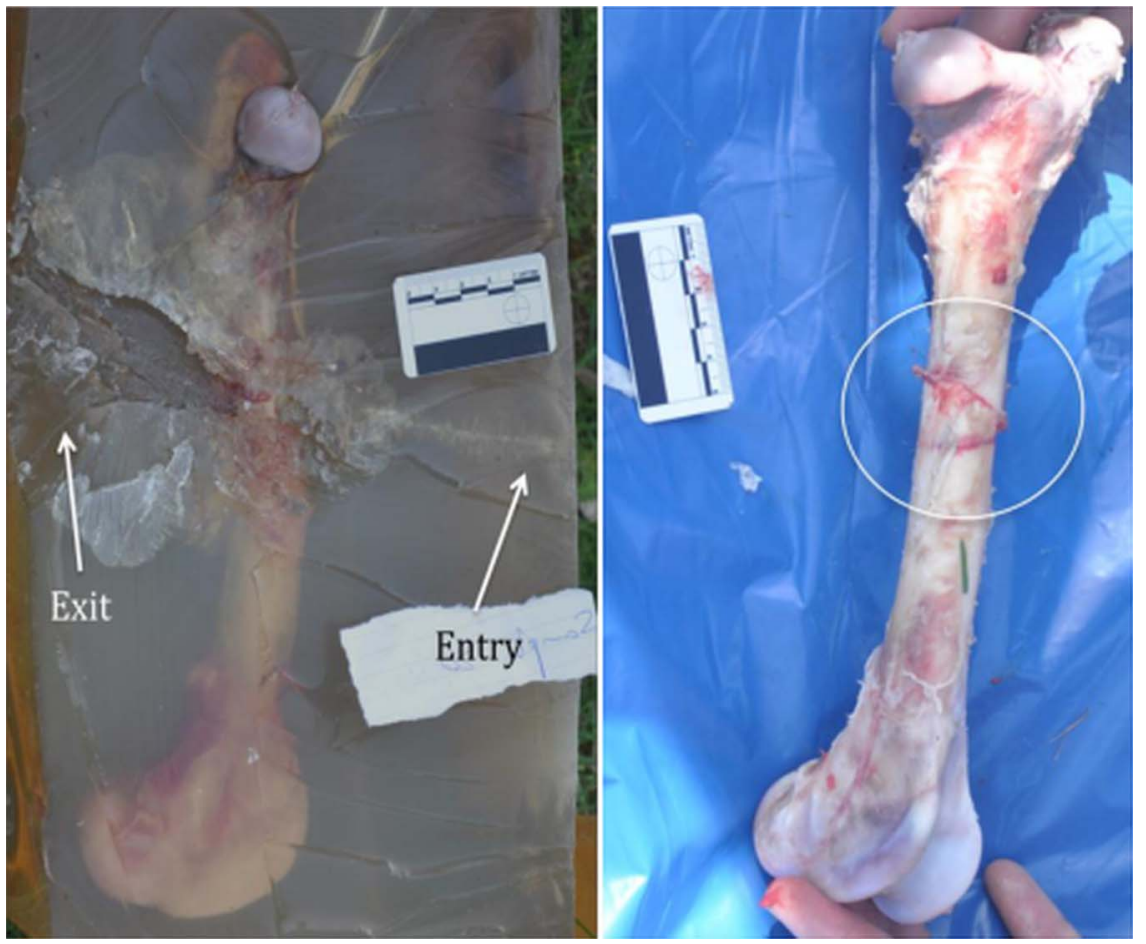

synchronised strain gauges and video in cadaveric bone. They concluded that the temporary cavity and not the sonic shock wave was responsible for the fracture. ${ }^{32}$

While we found no evidence that the collapsing and oscillation of the temporary cavity caused fracture, we did see it draw fracture fragments back towards their origin and in doing so may have further damaged the bone and surrounding soft tissues, or drawn foreign material into the wound, as suggested by previous publications. ${ }^{21-25}$

In this study, we found no correlation between the maximal pressures generated and fracture formation. Instead, we found the size and the proximity of the temporary cavity to the bone, as well as the energy transfer to the block ${ }^{41}$ and the amount of flexion of the bone determined the likelihood of fracture. In our study, the $5.56 \times 45 \mathrm{~mm}$ and $0.44^{\prime \prime}$ produced large temporary cavities (diameter 14 and $16 \mathrm{~cm}$, respectively) in comparison with the $7.62 \times 39$ and $9 \times 19 \mathrm{~mm}$ (diameter 10 and $5 \mathrm{~cm}$, respectively). This corresponded to an energy transfer to the gel block of approximately $400 \mathrm{~J}$ for the $7.62 \times 39$ and $9 \times 19 \mathrm{~mm}$, but four times this for the $5.56 \times 45 \mathrm{~mm}$ and $0.44^{\prime \prime}$. However, despite such large cavities and energy transfer, fracture only occurred with bullets close to the bone, with a maximum distance of $1 \mathrm{~cm}$ for the $5.56 \times 45 \mathrm{~mm}$, consistent with Dougherty et $a l^{32}$ and $3 \mathrm{~cm}$ for the $0.44^{\prime \prime}$. Under these circumstances, the expansion of the temporary cavity and radial displacement of the surrounding gel was seen to flex the bone rather than displace it as a unit without flexion. Once flexion surpassed $3 \mathrm{~mm}$ the bone was seen to fracture.

We left the bones free within the gelatin and not fixed, or loaded, at their ends, thus simulating a non-weight bearing limb. This allowed the bones to move, rather than just flex. For the $5.56 \times 45 \mathrm{~mm}$ at $1 \mathrm{~cm}$, the bone flexed and fractured without the bone moving significantly; however, beyond $1 \mathrm{~cm}$ the bone moved as a unit and flexion was insignificant. This may be related to the lower force being applied to the bone with more distant gunshot wounds, or the lower rate of force transfer. It
Figure 4 Time sequence of $0.44^{\prime \prime}$ shot $1 \mathrm{~cm}$ away from the bone. Note the femur is flipped in comparison with the images of the $5.56 \times 45 \mathrm{~mm}$, as this is a right femur and the previous was a left; however, entry is always from the right of each image in both sequences.

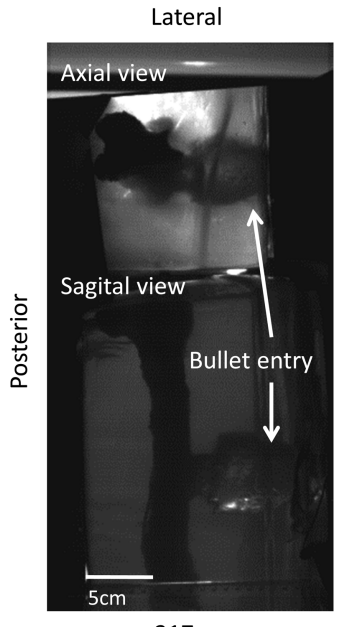

$317 \mu \mathrm{s}$

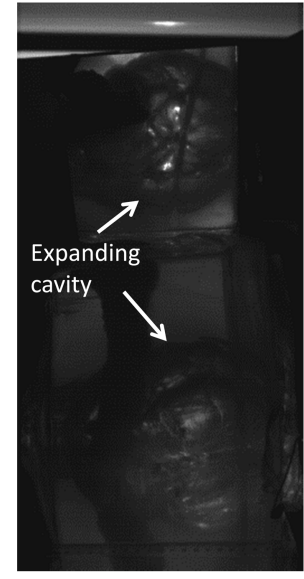

$2876 \mu \mathrm{s}$

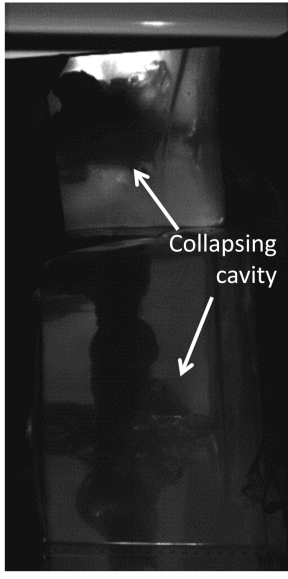

$9652 \mu \mathrm{s}$

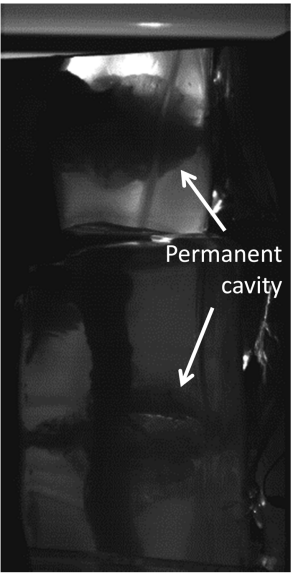

$28470 \mu \mathrm{s}$ 
Figure 5 Indirect fracture produced by a $0.44^{\prime \prime}$ bullet passing $1 \mathrm{~cm}$ away from the medial cortex. Note the superficial permanent cavity $(A)$ and the comminution (B).
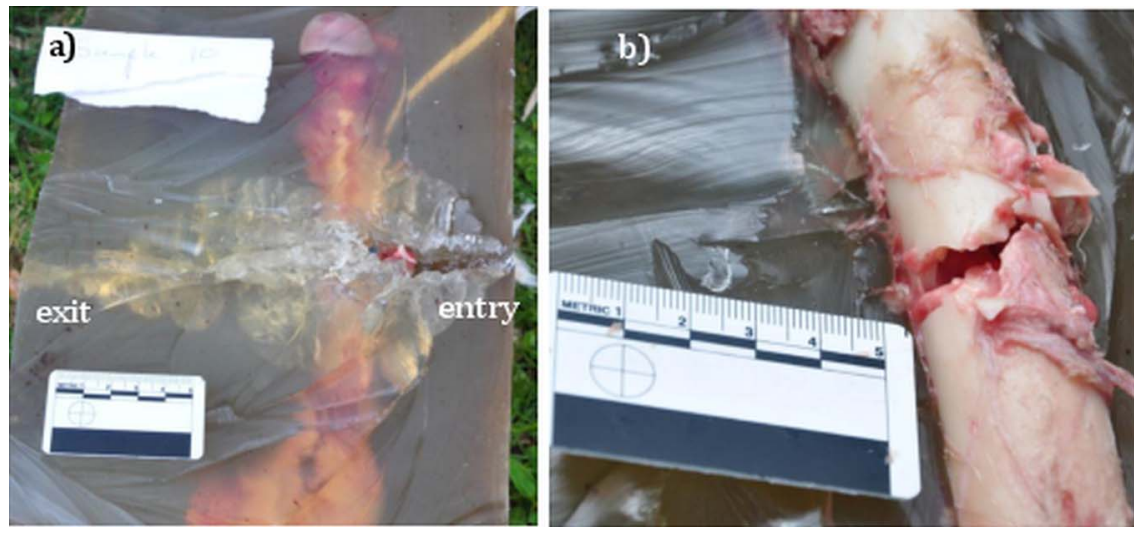

may also be due to the initial impact area of the displaced gel from the elliptical expanding cavity being larger with further bullet tracts, thus loading the bone over a larger area, rather than more localised loading. Similar results were seen with the $0.44^{\prime \prime}$, but in addition, we found that the closer the bullet was to the bone the greater the fracture comminution, which suggests more severe bony injury from the higher rate of energy deposition and energy flux, as suggested by previous authors. ${ }^{28}$ It would be worth further investigation with the bone ends loaded to simulate the weight bearing limb, as it is likely that fracture will occur with even more distant bullet tracts if the bone is unable to move and is thus forced to flex.

\section{CONCLUSIONS}

This work suggests that indirect fractures are caused by the radial displacement of soft tissue material by the expansion of the temporary cavity and relate to the proximity of the expanding cavity to the bone. Fractures occur from flexion of the bone and classically display wedge-shaped fracture patterns with the apex of the wedge pointing away from the expanding cavity. The primary factor determining bone fracture is the energy transferred into the tissues and therefore is much more likely for projectiles that tumble or deform.

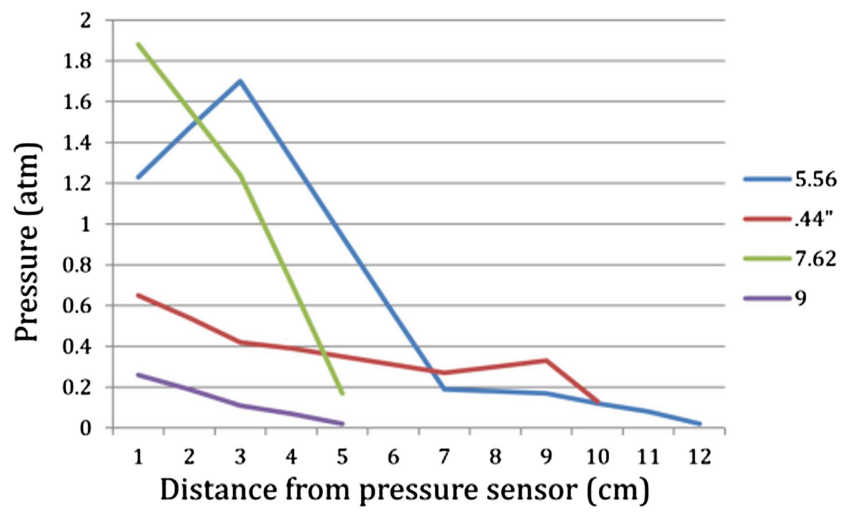

Figure 6 Maximum pressure recorded for each projectile at different distances from the sensor.

Acknowledgements The authors with to acknowledge Glynny Kieser for her editorial input.

Contributors DCK: principal investigator; DJC, IH: study design, implementation and analysis; SCIL: data analysis and writing; JCT, MVS, JAK: data interpretation and critical revision.

Competing interests None.
Ethical approval This was attained from the University of Otago animal ethics committee.

Provenance and peer review Not commissioned; externally peer reviewed.

\section{REFERENCES}

1 Saayman G. Gunshot wounds: medico-legal perspectives. CME 2006;24:131-6.

2 Bartlett CS. Clinical update: gunshot wound ballistics. Clin Orthop Relat Res 2003:408:28-57

3 Dougherty PJ, Vaidya R, Silverton CD, et al. Joint and long-bone gunshot injuries. JBJS [Am] 2009;91:980-97.

4 Directorate for Information Operations and Reports. Department of Defense. Military casualty information. http://siadapp.dmdc.osd.mil/personnel/CASUALTY/castop.htm

5 Champion HR, Holcomb JB, Lawnick MM, et al. Improved characterization of combat injury. J Trauma 2010;68:1139-50.

6 Hofmeister EP, Mazurek M, Ingari J. Injuries sustained to the upper extremity due to modern warfare and the evolution of care. J Hand Surg Am 2007;32:1141-7.

7 Belmont PJ, Goodman GP, Zacchilli M, et al. Incidence and epidemiology of combat injuries sustained during "the surge" portion of operation Iraq Freedom by a US army brigade combat team. J Trauma 2010;68:204-10.

8 Birch R, Raji AR. Repair of median and ulnar nerves: Primary suture is best. JBJS [Br] 1991;73:154-7.

9 Li M, Ma YY, Fu RX, et al. The characteristics of the pressure waves generated in the soft target by impact and its contribution to indirect bone fractures. J Trauma 1988;28:S104-9.

10 Bowen TE, Bellamy RF. Emergency war surgery: Second United States revision of the emergency war surgery NATO handbook. Washington, DC: US Department of Defence, United States Government Printing Office, 1988.

11 Fackler ML, Malinowski JA. The wound profile: A visual method for quantifying gunshot wound components. J Trauma 1985;25:522-9.

12 Tikka S, Cederberg A, Rokkanene P. Remote effects of pressure changes in anesthetized pigs wounded in the thigh. Acta Chir Scand 1982;508:167-73.

13 Woodruff CE. The causes of the explosive effect of modern small caliber bullets. NY Med J 1898;67:593-601.

14 Ryan JM, Cooper GJ, Haywood IR, et al. Field surgery on a future conventional battlefield: Strategy and wound management. Ann R Coll Surg Engl 1991;73:13-20

15 Thoresby FP. Cavitation: The wounding process of the high velocity missile, a review. J R Army Med Corps 1966;112:89-99.

16 Fackler ML. Wound ballistics: A review of common misconceptions. JAMA 1988;259:2730-6.

17 Charters $A C$, Charters $A C$. Wounding mechanism of very high velocity projectiles. J Trauma 1976;16:464-70.

18 Peters CE. Common misconceptions about the physical mechanisms in wound ballistics. J Trauma 1990:6:319-26.

19 Rybeck B. Missile wounding and haemodynamic effects of energy absorption. Acta Chir Scand 1974;450:1-32.

20 Maio Di. Gunshot wounds: Practical aspects of firearms, ballistics and forensic techniques 2nd ed. Boca Raton, FL: CRC Press, 1999.

21 Mendelson JA. The relationship between mechanism of wounding and principles of treatment of missile wounds. J Trauma 1991;31:1181-202.

22 Thoresby FP, Darlow HM. The mechanism of primary infection of bullet wounds Br J Surg 1967:54:359-61.

23 Dziemian AJ, Herget CM. Physical aspects of primary contamination of bullet wounds. Milit Surg 1950;106:294-9.

24 Dahlgren B, Berlin R, Janzon B, et al. The extent of muscle tissue damage following missile trauma one, six and twelve hours after the infliction of trauma, studied by the current method of debridement. Acta Chir Scand 1979:489:137-44. 
25 Bowyer GW, Cooper GJ, Rice P. Small fragment wounds: biophysics and pathophysiology. J Trauma 1996;40:S159-64.

26 Volgas DA, Stannard JP, Alonso JE. Ballistics: a primer for the surgeon. Injury 2005;36:373-9.

27 Dziemian AJ, Mendelson JA, Lindsey D. Comparison of the wounding characteristics of some commonly encountered bullets. J Trauma 1961;1:341-53.

28 Sellier KG, Kneubuehl BP. Wound ballistics and the scientific background. Amsterdam: Elsevier, 1994.

29 Callender GR, French RW. Wound ballistics: studies in the mechanism of wound production by rifle bullets. Military Surg 1935;77:177-201.

30 Harvey EN. The mechanism of wounding by high velocity missiles. P Am Philos Soc 1948:92:293-304.

31 Ramasamy A, Hill AM, Masouros S, et al. Blast-related fracture patterns: a forensic biomechanical approach. J R Soc Interface 2011:8:689-98.

32 Dougherty PJ, Sherman D, Dau N, et al. Ballistic fractures: indirect fracture to the bone. J Trauma 2011;71:1381-4.

33 McMillen JH. Shockwave pressures in water produced by impact of small spheres. Phys Rev 1945;68:198-209.
34 Janzon B, Hull JB, Ryan JM. Projectile-material interactions: soft tissue and bone. In: Cooper GJ, Dudley HAF, Gann DS, Little RA, Maynard RL.eds Scientific foundations of trauma. Oxford: Butterman-Heinemann, 1997.

35 Roberts VL. Strain gage techniques in biomechanics. Exp Mech 1966;6:19-22.

36 Biewener AA. In vivo measurement of bone strain and tendon forces. Biomechanics: structures and systems: a practical approach. Oxford University Press, 1992; 123-47.

37 Cronin DS, Falzon C. Characterization of 10\% ballistic gelatine to evaluate temperature, aging and strain rate effects. Exp Mech 2011;51:1197-206.

38 Ordog GJ, Wasserberger J, Balasubramanium S. Wound ballistics: Theory and practice. Ann Emerg Med 1984;13:1113-22.

39 Kress TA, Porta DJ, Snider JN, et al. Fracture patterns of human cadaver long bones. Brunner, Switzerland: IRCOBI, 1995.

40 Benham PP, Crawford RJ. Mechanics of engineering materials. Harlow, UK: Longman Scientific \& Technical, 1987.

41 Amato JJ, Billy LJ, Lawson NS, et al. High velocity missile injury. An experimental study of the retentive forces of tissue. Am J Surg 1974;127:454-9. 